\title{
Optimization of Culture Conditions for Hydrogen Production by an Anaerobic Bacteria Strain on Soluble Starch Using Response Surface Methodology
}

Hoa Thi Quynh Kieu*, Yen Thi Nguyen, Yen Thi Dang and Binh Thanh Nguyen

Institute of Biotechnology, Vietnam Academy of Science and Technology, Hanoi, Vietnam

\begin{abstract}
Bio-hydrogen is a clean source of energy with no harmful by-products produced during its combustion so hydrogen is potentially sustainable energy carrier for future. Therefore, bio-hydrogen produced by anaerobic bacteria in dark fermentation has attracted worldwide attention as renewable energy. However, capability of hydrogen production of these bacteria depends on major factors as substrates, iron-containing hydrogenase, reduction agent, $\mathrm{pH}$ and temperature. In this study, the Response Surface Methodology (RSM) with Central Composite Design (CCD) was employed to improve hydrogen production of a hydrogen-producing anaerobic bacteria strain that was isolated from animal waste in Phu Linh, Soc Son, Vietnam (PL strain). The hydrogen production process was investigated as a function of three critical factors: soluble starch concentration (8-12 $\left.\mathrm{g} \mathrm{L}^{-1}\right)$, ferrous iron concentration (100-200 $\left.\mathrm{mg} \mathrm{L}^{-1}\right)$ and L-cysteine concentration (300-500 $\left.\mathrm{mg} \mathrm{L}^{-1}\right)$. RSM analysis showed that all three factors had significant influences on the hydrogen production. Among them, ferrous iron concentration presented a greatest influence. The optimum hydrogen concentration of $1030 \mathrm{ml} / \mathrm{L}$ medium occurred with $10 \mathrm{~g} \mathrm{~L}^{-1}$ of soluble starch, $150 \mathrm{mg} \mathrm{L}^{-1}$ of ferrous iron and $400 \mathrm{mg} \mathrm{L}^{-1}$ of L-cysteine after 48 hour- anaerobic fermentation. The hydrogen concentration that produced by the PL strain had increased to two times after using RSM. The obtained results indicated that RSM with CCD can be used as a technique to optimize culture conditions for enhancement of hydrogen production by the selected anaerobic bacteria strain. The production of hydrogen from low-cost organic substrates as soluble starch using anaerobic fermentation methods may be one of the most promising methods.
\end{abstract}

Keywords: Anaerobic bacteria strain; Bio-hydrogen; Dark fermentation; Response surface methodology

\section{Introduction}

Fossil fuels are not renewable and will be exhausted sooner or later. In addition, fossil fuel consumption caused global warming and environmental pollution. Thus, it is necessary to look for an alternative energy sources that are renewable and environmentally friendly. Hydrogen $\left(\mathrm{H}_{2}\right)$ is an alternative energy source in the future because it has high specific energy content per unit mass $(122 \mathrm{~kJ} / \mathrm{g})$ and produces no carbon-based emissions. Among various hydrogen production processes, biological methods are known to be less energy intensive than chemical or electrochemical ones since they are carried out at an ambient temperature and pressure [1,2].

However, one of the challenges of bio-hydrogen production processes is the feasibility of producing $\mathrm{H}_{2}$ at a commercial scale with a low cost to meet the need of sufficient and cost-effective energy supply. Consequently, the substrate used for fermentative $\mathrm{H}_{2}$ production must be abundant, easily available, and inexpensive. From those aspects, starch obtained from crop or food industry wastes could be a commercially viable Biohydrogen feedstock. In hydrogen production processes, dark fermentative hydrogen production from direct starch utilization was achieved using starch-fermenting bacteria, such as Clostridium butyricum [3].

Besides to substrate source, ferrous iron and L-cysteine are two important elements in dark fermentation hydrogen production. Ferrous iron is an essential element to form hydrogenase and ferredoxin, which is responsible for electrons transfer during hydrogen production process. L-cysteine is also an important nutrient for hydrogenase formation. In addition, L-cysteine, as a reducing agent, has the ability to reduce the Oxidation-Reduction Potential (ORP) value in the fermentation system, which enhances the growth of some hydrogen producing bacteria, thus considerably increasing the cumulative hydrogen production [4-
7]. Many studies have shown the effects of concentrations of soluble starch, ferrous iron and L-cysteine on hydrogen productivity based on the "one-variable-at-a-time" approach. However, these just carried out on individual factor but not mutual factors. So those results could not explain the mutual interactions among the independent variables and guarantee the determination of optimal conditions $[4,5,8,9]$. To the best of our knowledge, no study has ever investigated the interactions among these factors on the efficiency of the dark fermentation with soluble starch as substrate for hydrogen production. Therefore, the interactive effects of three key factors (soluble starch, ferrous iron and L-cysteine) were investigated in this study to maximize the hydrogen production by CCD of RSM [10-13].

The aim of this study was conducted to explore the effects of three independent factors (soluble starch, ferrous iron and L-cysteine) and interaction among them on $\mathrm{H}_{2}$ fermentation by an anaerobic bacteria strain (PL strain) using RSM, and find the optimum conditions for maximizing $\mathrm{H}_{2}$ production. The obtained results showed that the RSM with CCD was useful tool to finding the optimum condition for hydrogen producing by PL strain. The anaerobic bacteria (PL strain) had a great potential to produce $\mathrm{H}_{2}$ with soluble starch as substrate.

*Corresponding author: Hoa Thi Quynh Kieu, Institute of Biotechnology, Vietnam Academy of Science and Technology, 18 Hoang Quoc Viet, Cau Giay, Hanoi, Vietnam, Tel: +840437562000; Fax: +840438363144; E-mail: ktquynhhoa@ibt.ac.vn/kieuthiquynhhoa@gmail.com

Received November 02, 2015; Accepted December 03, 2015; Published December 07, 2015

Citation: Kieu HTQ, Nguyen YT, Dang YT, Nguyen BT (2015) Optimization of Culture Conditions for Hydrogen Production by an Anaerobic Bacteria Strain on Soluble Starch Using Response Surface Methodology. J Bioprocess Biotech 5: 265 doi:10.4172/2155-9821.1000265

Copyright: $\odot 2015 \mathrm{Kieu} \mathrm{HTQ}$, et al. This is an open-access article distributed under the terms of the Creative Commons Attribution License, which permits unrestricted use, distribution, and reproduction in any medium, provided the original author and source are credited. 
Citation: Kieu HTQ, Nguyen YT, Dang YT, Nguyen BT (2015) Optimization of Culture Conditions for Hydrogen Production by an Anaerobic Bacteria Strain on Soluble Starch Using Response Surface Methodology. J Bioprocess Biotech 5: 265 doi:10.4172/2155-9821.1000265

Page 2 of 6

\section{Materials and Methods}

\section{Inoculum}

The anaerobic hydrogen producing bacteria strain (PL strain) isolated from animal waste in Phu Linh village, Soc Son district, Hanoi, Vietnam was used as an inoculum.

\section{Batch experiment set-up}

The batch experiments were designed by RSM to study the effect of concentration of soluble starch, ferrous iron and L-cysteine on hydrogen production. The inoculum $(5 \% \mathrm{v} / \mathrm{v})$ was supplemented into $120 \mathrm{ml}$ serum bottles with a working volume of $80 \mathrm{ml}$. The air in the head space of the serum bottles was removed by passing argon gas through the medium and the head space to provide anaerobic condition.

The medium used for fermentation consisted of $\left(\mathrm{g} \mathrm{L}^{-1}\right)$ : peptone 4; meat extracts 2; yeast extract $1 ; \mathrm{NaCl} 2 ; \mathrm{K}_{2} \mathrm{HPO}_{4} 1.5 ; \mathrm{MgCl}_{2} .6 \mathrm{H}_{2} \mathrm{O}$ $0.6 ; \mathrm{FeSO}_{4} .7 \mathrm{H}_{2} \mathrm{O} 0.2$; trace element $10 \mathrm{ml}\left(\mathrm{MnSO}_{4} \cdot 7 \mathrm{H}_{2} \mathrm{O} 0.01 ; \mathrm{ZnSO}_{4}\right.$. $7 \mathrm{H}_{2} \mathrm{O} 0.05 ; \mathrm{H}_{3} \mathrm{BO}_{3} 0.01 ; \mathrm{CaCl}_{2} .2 \mathrm{H}_{2} \mathrm{O}, 0.01 ; \mathrm{Na}_{2} \mathrm{MoO}_{4} 0.01 ; \mathrm{CoCl}_{2} .6 \mathrm{H}_{2} \mathrm{O}$ 0.2 ); vitamin solution $10 \mathrm{ml}$ (riboflavin 0.025 ; citric acid 0.02 ; folic acid 0.01; para-aminobenzoic acid 0.01); soluble starch (6.95-13.05 $\left.\mathrm{g} \mathrm{L}^{-1}\right)$, ferrous iron (73.77-226.23 mg L-1) and L-cysteine (247.54-552.46 mg $\left.\mathrm{L}^{-1}\right)$ concentration were added into the medium according to various concentrations [13]. The initial $\mathrm{pH}$ of the medium was adjusted to 6.5 and the operation temperature was controlled at $30^{\circ} \mathrm{C}$.

\section{Full factorial central composite design for optimization of} hydrogen production

Optimization studies with CCD were carried out by three variables including initial concentration of soluble starch, ferrous iron and L-cysteine (Tables 1 and 2). The hydrogen production was selected as the dependent output variable. For statistical calculations, the relation between the coded values and real values are described according to the following equation:

$$
\mathrm{x}_{\mathrm{i}}=\frac{\left(\mathrm{X}_{\mathrm{i}}-\mathrm{X}_{\mathrm{o}}\right)}{\Delta \mathrm{X}_{\mathrm{i}}}
$$

Where $\mathrm{X}$ is a coded value of the variable (Table 1 ) of the variable $\mathrm{X}$ $\mathrm{X}_{\mathrm{i}}$ is the real value of the $\mathrm{i}^{\text {th }}$ independent variable. $\mathrm{X}$ is the real value of $\mathrm{X}_{\mathrm{i}}$ at the center point and $\Delta \mathrm{X}_{\mathrm{i}}$ is the step change of value. Initial soluble starch $\left(\mathrm{X}_{1}\right)$, initial ferrous iron $\left(\mathrm{X}_{2}\right)$, initial L-cysteine concentration $\left(\mathrm{X}_{3}\right)$ were chosen as three independent factors in the experiment design. A quadratic model was used to evaluate the optimization of key factor:

$$
Y_{i}=\beta_{o}+\sum \beta_{i} x_{i}+\sum \beta_{i i} x_{i}^{2}+\sum \beta_{i j} X_{i} X_{j}
$$

Where $Y_{i}$ is the predict response, $\beta_{\mathrm{o}}$ is constant, $\beta_{\mathrm{i}}$ is the linear coefficient, $\beta_{\mathrm{ii}}$ is the squared coefficient, and $\beta_{\mathrm{ij}}$ is the interaction coefficient.

The data analysis was calculated and analyzed using the "Design Expert" software (Version 7.1, Stat-Ease Inc., Minneapolis, USA). Statistical analysis of the model was performed to evaluate the analysis of variance (ANOVA) [14].

\section{Analytical methods}

Soluble starch concentration was measured by starch-iodide method. The substrate utilization was the ratio of starch consumption and initial amount of starch [15].

The evolved gas mixture in the headspace of the reactor was collected in a gas collector by displacement method at room temperature and atmospheric pressure. The quantity and composition of gas products (mainly, $\mathrm{H}_{2}$ and a little of $\mathrm{CO}_{2}$ and $\mathrm{H}_{2} \mathrm{~S}$ ) were determined in a gas chromatograph GC-TCD (Thermo Trace GC-Thermo Electro-USA) equipped with a Thermal Conductivity Detector (TCD) and a column packed Molecular sieve $13 \times 5 \mathrm{~m}$. The operational temperatures of the oven and the detector were $50^{\circ} \mathrm{C}$ and $200^{\circ} \mathrm{C}$, respectively. Heli was used as the carrier gas at a flow rate of $25 \mathrm{~mL} \mathrm{~min}^{-1}$.

\section{Results and Discussion}

\section{Levels of the independent variables and experimental ranges}

Ranges of variables were chosen basically on investigating the effect of each variable on hydrogen production in batch experiments. Finally, levels of the independent variables were selected including: soluble starch concentration (8-12 $\left.\mathrm{g} \mathrm{L}^{-1}\right)$; ferrous iron concentration (100-200 $\left.\mathrm{mg} \mathrm{L}^{-1}\right)$; $\mathrm{L}$-cysteine (300-500 $\left.\mathrm{mg} \mathrm{L}^{-1}\right)$. Each of the variables was coded at five levels: $-\alpha,-1,0,+1$ and $+\alpha$ (Table 1 ).

Based on CCD, a design of 20 experiments (Table 2) was formulated for three factorial $\left(2^{3}\right)$ design and six replicates at the central points, six star points were employed to the second-order polynomial model. The optimum values of the selected variables were obtained by solving regression equation and also by analyzing the response surface spots (Equation 3).

\section{Optimization of the key factors for hydrogen production by PL strain}

Soluble starch, ferrous iron and L-cysteine selected as key parameters were investigated the interactive effects to maximize the hydrogen production by CCD of RSM. By applying multiple regression analysis on the experimental data (Table 2), the following second order polynomial equation was established to explain the hydrogen production:

$$
\begin{aligned}
& \mathrm{Y}_{\mathrm{H} 2}=-7243.21+617.38 * \mathrm{X}_{1}+19.61 * \mathrm{X}_{2}+16.99 * \mathrm{X}_{3}-0.11 * \mathrm{X}_{1} \\
& * \mathrm{X}_{2}-0.23 * \mathrm{X}_{1} * \mathrm{X}_{3}-0.002 * \mathrm{X}_{2} * \mathrm{X}_{3}-23.98 * \mathrm{X}_{1}{ }^{2}-0.06 * \mathrm{X}_{2}{ }^{2}-0.018 * \mathrm{X}_{3}{ }^{2}
\end{aligned}
$$

Where $\mathrm{Y}$ is the predicted hydrogen yield; $\mathrm{X}_{1}, \mathrm{X}_{2}$ and $\mathrm{X}_{3}$ are the coded values of soluble starch, ferrous iron and $\mathrm{L}$-cysteine, respectively.

The analysis of variance (ANOVA) was conducted to test the significance of the fit of the second-order polynomial equation for the experimental data as shown in Table 3. The P-values are used as a tool to check significance of each variable, which also indicate the interaction strength between each independent variable. The smaller $\mathrm{P}$-values, the bigger the significance of the corresponding variable [13].

The Model F-value of 507.67 implies the model is significant. There is only less than $99.99 \%$ ( $p$-value $<0.0001)$ chance that a "Model $\mathrm{F}$ -value" could occur due to noise.

The "Lack of Fit F-value" of 0.93 implies the "Lack of Fit" is not significant relative to the pure error. There is a $52.85 \%$ chance that a "Lack of Fit F-value" this large could occur due to noise. Non-significant lack of fit is good.

Here the R-squared value was $99.78 \%$, which could explain $99.78 \%$ variability of the response. It indicates a good agreement between experiments and predicted values. It implies that the mathematical model is very reliable for hydrogen production in the present study.

The "Pred R-squared" of $98.99 \%$ is in reasonable agreement with the "Adj R-Squared" of 99.59\%. "Adeq Precision" measures the signal to noise ratio. A ratio greater than 4 is desirable. The ratio of 68.109 indicates an adequate signal. This model can be used to navigate the design space [14] (Table 3). 
Citation: Kieu HTQ, Nguyen YT, Dang YT, Nguyen BT (2015) Optimization of Culture Conditions for Hydrogen Production by an Anaerobic Bacteria Strain on Soluble Starch Using Response Surface Methodology. J Bioprocess Biotech 5: 265 doi:10.4172/2155-9821.1000265

Page 3 of 6

\begin{tabular}{|c|c|c|c|c|c|}
\hline \multirow{2}{*}{ Independent variables } & \multicolumn{5}{|c|}{ Range and level coded value $\left(x_{i}\right)$} \\
\hline & $-\alpha$ & -1 & 0 & +1 & $+\alpha$ \\
\hline $\mathrm{X}_{1}$ : initial soluble starch $\left(\mathrm{g} \mathrm{L}^{-1}\right)$ & 6.95 & 8 & 10 & 12 & 13.05 \\
\hline $\mathrm{X}_{2}:$ initial ferrous iron $\left(\mathrm{mg} \mathrm{L}^{-1}\right)$ & 73.77 & 100 & 150 & 200 & 226.23 \\
\hline $\mathrm{X}_{3}:$ initial L-cysteine $\left(\mathrm{mg} \mathrm{L}^{-1}\right)$ & 247.54 & 300 & 400 & 500 & 552.46 \\
\hline
\end{tabular}

Table 1: Experimental range and levels of the independent variables.

\begin{tabular}{|c|c|c|c|c|c|c|c|c|c|}
\hline \multirow{3}{*}{$\begin{array}{l}\text { Run } \\
\text { No. }\end{array}$} & \multicolumn{6}{|c|}{ Independent values } & \multicolumn{2}{|c|}{ Hydrogen production $\left(\mathrm{ml} \mathrm{L}^{-1}\right)$} & \multirow[t]{3}{*}{$\begin{array}{l}\text { Categorical } \\
\text { factor levels }\end{array}$} \\
\hline & \multicolumn{3}{|c|}{ Coded values } & \multicolumn{3}{|c|}{ Real values } & Observed & Predicted & \\
\hline & $\mathrm{X}_{1}$ & $\mathrm{X}_{2}$ & $\mathrm{X}_{3}$ & $\mathrm{X}_{1}$ & $\mathrm{X}_{2}$ & $\mathrm{X}_{3}$ & & & \\
\hline 1 & +1 & +1 & +1 & 12 & 200 & 500 & 650 & 644.43 & $\begin{array}{c}\text { Fractional } \\
2^{3} \text { fractional } \\
\text { factorial points }\end{array}$ \\
\hline 2 & +1 & +1 & -1 & 12 & 200 & 300 & 700 & 702 & \\
\hline 3 & +1 & -1 & -1 & 12 & 100 & 300 & 600 & 599.63 & \\
\hline 4 & +1 & -1 & +1 & 12 & 100 & 500 & 575 & 584.4 & \\
\hline 5 & -1 & +1 & -1 & 8 & 200 & 300 & 520 & 517.56 & \\
\hline 6 & -1 & +1 & +1 & 8 & 200 & 500 & 640 & 647.43 & \\
\hline 7 & -1 & -1 & -1 & 8 & 100 & 300 & 360 & 372.53 & \\
\hline 8 & -1 & -1 & +1 & 8 & 100 & 500 & 540 & 544.81 & \\
\hline 9 & $+\alpha$ & 0 & 0 & 13.05 & 150 & 400 & 850 & 849.46 & $\begin{array}{l}\text { Star point (6 } \\
\text { points) }\end{array}$ \\
\hline 10 & $-\alpha$ & 0 & 0 & 6.95 & 150 & 400 & 690 & 678.56 & \\
\hline 11 & 0 & $+\alpha$ & 0 & 10 & 226.23 & 400 & 540 & 535.35 & \\
\hline 12 & 0 & $-\alpha$ & 0 & 10 & 73.76 & 400 & 600 & 585.85 & \\
\hline 13 & 0 & 0 & $+\alpha$ & 10 & 150 & 552.46 & 630 & 622.67 & \\
\hline 14 & 0 & 0 & $-\alpha$ & 10 & 150 & 247.54 & 540 & 544.81 & \\
\hline 15 & 0 & 0 & 0 & 10 & 150 & 400 & 960 & 987.02 & $\begin{array}{l}\text { Central points } \\
\text { (6 points) }\end{array}$ \\
\hline 16 & 0 & 0 & 0 & 10 & 150 & 400 & 992 & 987.02 & \\
\hline 17 & 0 & 0 & 0 & 10 & 150 & 400 & 990 & 987.02 & \\
\hline 18 & 0 & 0 & 0 & 10 & 150 & 400 & 993 & 987.02 & \\
\hline 19 & 0 & 0 & 0 & 10 & 150 & 400 & 994 & 987.02 & \\
\hline 20 & 0 & 0 & 0 & 10 & 150 & 400 & 993 & 987.02 & \\
\hline
\end{tabular}

Table 2: Central composite experimental design with three independent variables.

\section{Effect interaction among of three factors on hydrogen production}

Response surface plots are shown in Figure 1, which depict the interactions between two variables by keeping the other variables at their zero levels for hydrogen production.

\section{Effect of interaction between soluble starch and ferrous iron}

Interaction effect of soluble starch and ferrous iron on hydrogen production was displayed by the response surface plot in Figure 1a and Tables 2 and 3 with concentration of soluble starch and ferrous iron range from 8 to $12 \mathrm{~g} \mathrm{~L}^{-1}, 100$ to $200 \mathrm{mg} \mathrm{L}^{-1}$, respectively. $P$-values of each factor (soluble starch and ferrous iron) less than 0.05 indicated these factors all impact on hydrogen production. The hydrogen production was also influence by the interaction between two factors because $p$-valuable $(p<0.0403)$ was less than 0.05 (Table 2$)$.

Figure 1a and Table 2 show that hydrogen production decrease when soluble starch and ferrous iron concentration at level $-1\left(8 \mathrm{~g} \mathrm{~L}^{-1}\right.$ with soluble starch and $100 \mathrm{mg} \mathrm{L}^{-1}$ with ferrous iron), gas mixture volume obtained about $360 \mathrm{ml} \mathrm{L}^{-1}$. With higher soluble starch concentration at level $+1\left(12 \mathrm{~g} \mathrm{~L}^{-1}\right)$, gas mixture yield increase from $575 \mathrm{ml} \mathrm{L}^{-1}$ to $700 \mathrm{ml}$ $\mathrm{L}^{-1}$ when ferrous iron concentration changes at two level -1 and $+1(100$ $\mathrm{mg} \mathrm{L} \mathrm{L}^{-1}$ and $200 \mathrm{mg} \mathrm{L}^{-1}$ ).
At central points, level 0 with $10 \mathrm{~g} \mathrm{~L}^{-1}$ soluble starch, total gas yield was about 600 and $540 \mathrm{ml} \mathrm{L}^{-1}$ with ferrous iron at level $-\alpha(73.76 \mathrm{mg}$ $\left.\mathrm{L}^{-1}\right)$ and level $+\alpha\left(226.23 \mathrm{mg} \mathrm{L}^{-1}\right)$, respectively. Although ferrous iron concentration at level $+\alpha$ was so higher than that at level $-\alpha$, total gas yield has an approximate value. It could be superfluous ferrous iron showed slightly inhibitive influence on hydrogen production in this study.

Maximum total gas production obtained approximately 995 $\mathrm{ml} \mathrm{L}^{-1}$ with $10 \mathrm{~g}$ soluble starch $\mathrm{L}^{-1}$ and $150 \mathrm{mg}$ ferrous iron $\mathrm{L}^{-1}$. The concentration of ferrous iron and soluble starch used in this study were lower than that of other studies [2,3]. Consequently, external iron addition could improve bio-hydrogen production since hydrogenase, key enzyme on hydrogen production, contains iron at the active site. Increasing of iron concentration improve hydrogenase activity thus enhanced bio-hydrogen production. Nonetheless, too much iron concentration may be toxic for hydrogen-producing microorganisms $[9,15]$. Optimum concentration of soluble starch and ferrous iron for hydrogen production in this study was the same results reported by Yang et al. [16].

\section{Effect of interaction among soluble starch and L-cysteine}

Interaction between two variables (soluble starch and L-cysteine) on hydrogen production was displayed by the response surface plot 


\begin{tabular}{|l|l|l|l|l|l|}
\hline Source & $\begin{array}{l}\text { Sum of } \\
\text { Squares }\end{array}$ & df & $\begin{array}{l}\text { Mean } \\
\text { Square }\end{array}$ & $\begin{array}{l}\text { F } \\
\text { Value }\end{array}$ & $\begin{array}{l}\text { p-value } \\
\text { Prob }>F\end{array}$ \\
\hline Model & 743801.02 & 9 & 82644.55 & 507.67 & $<0.0001$ \\
\hline$X_{1}$ - Soluble starch & 39734.13 & 1 & 39734.13 & 244.078 & $<0.0001$ \\
\hline$X_{2}$-Ferrous iron & 33242.54 & 1 & 33242.54 & 204.2 & $<0.0001$ \\
\hline$X_{3}-$-L-cystein & 10372.44 & 1 & 10372.44 & 63.72 & $<0.0001$ \\
\hline$X_{1} X_{2}$ & 903.13 & 1 & 903.13 & 5.55 & 0.0403 \\
\hline$X_{1} X_{3}$ & 17578.13 & 1 & 17578.13 & 107.98 & $<0.0001$ \\
\hline$X_{2} X_{3}$ & 903.13 & 1 & 903.13 & 5.55 & 0.0403 \\
\hline$X_{1}^{\wedge 2}$ & 99463.50 & 1 & 99463.50 & 610.98 & $<0.0001$ \\
\hline$X_{2}^{\wedge 2}$ & 208665.97 & 1 & 208665.96 & 1281.79 & $<0.0001$ \\
\hline$X_{3}^{\wedge 2}$ & 332938.06 & 1 & 332938.06 & 2045.16 & $<0.0001$ \\
\hline Residual & 1627.93 & 10 & 162.79 & & \\
\hline Lack of Fit & 786.59 & 5 & 157.32 & 0.93 & 0.5285 \\
\hline Pure Error & 841.33 & 5 & 168.27 & & $<0.0001$ \\
\hline Cor Total & 745428.95 & 19 & & & $<0.0001$ \\
\hline R-Squared: 0.9978 & $\begin{array}{l}\text { Adj R-Squared: } \\
0.9959\end{array}$ & $\begin{array}{l}\text { Pred } \\
\text { R-Squared: }\end{array}$ & Adeq Precission: \\
\hline & & & 0.9899 & & \\
\hline
\end{tabular}

Table 3: ANOVA for response surface quadratic model for hydrogen production.

in Figure $1 \mathrm{~b}$ and Table 3. $P$-value of two factors $\left(p_{\mathrm{x} 1 \mathrm{x} 3}<0.0001\right)$ in Table 3 showed that interaction of those has significant to hydrogen production. This interaction between soluble starch and L-cysteine was stronger effect than ferrous iron and L-cysteine. Taherdanak et al. used CCD to find optimum factor as starch, ferrous iron and nickel via mesophilic dark fermentation. Results showed that starch and ferrous iron concentration were found to be the most important factor affecting the hydrogen production [8]. The different results might be explained that hydrogen was produced by mixed culture not pure culture. Table 2 and Figure $1 b$ show that soluble starch concentration at level $+1(12$ $\left.\mathrm{g} \mathrm{L}^{-1}\right)$, total gas yield obtained from 575 to $700 \mathrm{ml} \mathrm{L}^{-1}$ with L-cysteine concentration at level -1 and +1 . Total gas yield increased when starch concentration $\left(8 \mathrm{~g} \mathrm{~L}^{-1}\right)$ and L-cysteine $\left(100 \mathrm{mg} \mathrm{L}^{-1}\right)$ at level -1 .

At central points, with $10 \mathrm{~g}$ soluble starch $\mathrm{L}^{-1}$ and $400 \mathrm{mg} \mathrm{L}$-cysteine $\mathrm{L}^{-1}$, maximum total gas achieved above $990 \mathrm{ml} \mathrm{L}^{-1}$. According to Houqing et al., maximum hydrogen production obtained by Enterobacterium bacterium M580 when $300 \mathrm{mg} \mathrm{L-cysteine} \mathrm{L}^{-1}$ was added into the culture with substrate as glucose [4]. Yuan et al. investigated the effect of L-cysteine on dark fermentative $\mathrm{H}_{2}$ production and demonstrated that the dark fermentative hydrogen production using anaerobic mixed cultures was significantly enhanced by adding a small amount of L-cysteine (0.1-1.0 $\mathrm{mM})$ as nutrient solution. The authors showed that optimum L-cysteine was $0.6 \mathrm{mM}\left(72.69 \mathrm{mg} \mathrm{L}\right.$-cysteine $\left.\mathrm{L}^{-1}\right)$ for maximum hydrogen production on dark fermentation on substrate as sucrose [17].

\section{Effect of interaction among ferrous iron and L-cysteine}

Interaction between two variables (ferrous iron and L-cysteine) on hydrogen production was displayed by the response surface plot in Figure $1 \mathrm{c}$ and Table 3. $P$-value of each variable less than 0.0001 showed the important role of these factors on hydrogen production. In addition, $P$-value of $\mathrm{X}_{2} \mathrm{X}_{3}$ less than 0.05 demonstrated that interaction between two variables had effect to hydrogen production (Table 3 ).

The response surface plot in Figure 1c showed the interactive effect between ferrous iron and L-cysteine when soluble starch concentration at level 0 . When ferrous iron concentration at level-1 $\left(100 \mathrm{mg} \mathrm{L}^{-1}\right)$, total gas production all decreased under $600 \mathrm{ml} \mathrm{L}^{-1}$ at level $-1\left(300 \mathrm{mg} \mathrm{L}^{-1}\right)$ and $+1\left(500 \mathrm{mg} \mathrm{L}^{-1}\right) \mathrm{L}$-cysteine concentration. At level +1 , $-\alpha$ of ferrous concentration, total gas obtained $600-650 \mathrm{ml} \mathrm{L}^{-1}$ at level $+1,-1$ and 0 . $\mathrm{Al}$ level $+\alpha$ ferrous iron and level $0 \mathrm{~L}$-cysteine, hydrogen yield obtained
$540 \mathrm{ml} \mathrm{L}^{-1}$. Maximum total gas production achieved above $990 \mathrm{ml} \mathrm{L}^{-1}$ at

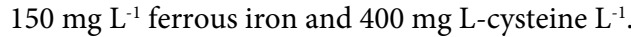

Yang et al. indicated that the highest gas yield at initial iron concentration lower than $100 \mathrm{mg} \mathrm{Fe}^{2+} \mathrm{L}^{-1}$. Initial iron concentration $55.3 \mathrm{mg} \mathrm{Fe}^{2+} \mathrm{L}^{-1}$ was reported producing maximum hydrogen yield from soluble starch by mixed anaerobes under mesophilic temperature [16]. The highest bio-hydrogen production obtained from sucrose by mixed microbes under mesophilic condition when initial iron concentration $73.47 \mathrm{mg} \mathrm{Fe}^{2+} \mathrm{L}^{-1}$ [15]. Whereas, some studies reported optimal initial iron concentration higher than $300 \mathrm{mg} \mathrm{Fe}^{2+} \mathrm{L}^{-1}$, initial ferrous concentration $300 \mathrm{mg} \mathrm{Fe}{ }^{2+} \mathrm{L}^{-1}$ was optimal for hydrogen production from sucrose [11]. Furthermore, the highest hydrogen yield from sucrose was found at initial iron concentration $587.76 \mathrm{mg}$ $\mathrm{Fe}^{2+} \mathrm{L}^{-1}[2]$. Bao et al. reported that adding trace elements $\left(\mathrm{Fe}^{2+}\right)$ and L-cysteine the hydrogen yields were higher than for control [5].

\section{Fermentation under the optimal conditions}

The maximum total gas production was determined about 1030 $\mathrm{ml} \mathrm{L}^{-1}$ by calculating via CCD. The optimum condition for total gas producing by $\mathrm{PL}$ strain was $10 \mathrm{~g}$ soluble starch $\mathrm{L}^{-1}, 150 \mathrm{mg} \mathrm{Fe}^{2+} \mathrm{L}^{-1}$ and $400 \mathrm{mg} \mathrm{L}^{-1}$ cysteine $\mathrm{L}^{-1}$.

This strain was fermented in basal medium with $600 \mathrm{ml}$ by adding $10 \mathrm{~g}$ soluble starch $\mathrm{L}^{-1}, 150 \mathrm{mg} \mathrm{Fe}^{2+} \mathrm{L}^{-1}$ and $400 \mathrm{mg} \mathrm{L}$-cysteine $\mathrm{L}^{-1}$ in fact. In optimum condition, PL strain consumed $98 \%$ soluble starch to produce $1030 \mathrm{ml}$ total gas/L medium. The results of gas analysis by GC-TCD showed that a maximum hydrogen production of $91.85 \mathrm{ml}$ $\mathrm{H}_{2} / \mathrm{g}$ starch was achieved under optimum condition because $\mathrm{H}_{2}$ gas occupied a volume of $91 \%$. Similar result was obtained by Zhang et al. The author reported that $92 \mathrm{ml} \mathrm{H_{2 }} / \mathrm{g}$ soluble starch was produced by the Thermoanaerobacterium under thermophilic condition [18].

The obtained hydrogen volume increased to two times in comparison with previous studies that investigated the suitable

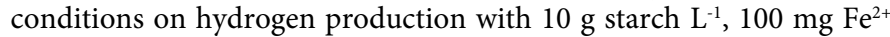
$\mathrm{L}^{-1}$ and $500 \mathrm{mg} \mathrm{L-cysteine} \mathrm{L}^{-1}$ (data not shown) [19].

RSM was used to optimize critical factors for hydrogen fermentation by bacteria in many studies. Using RSM, Guo et al. indicated that the most important factor for hydrogen producing by Ethanoligenens harbinense 49 were glucose [13], $\mathrm{Fe}^{2+}$ and $\mathrm{Mg}^{2+}$. Maximum $\mathrm{H}_{2}$ yield obtained in optimum condition was $2.20 \mathrm{~mol} / \mathrm{mol}$ glucose [10]. Yang et al. determined the important factors for hydrogen production by an anaerobic was temperature, $\mathrm{pH}$ and glucose. The optimum value of these factors was detected by RSM. At this condition, maximum $\mathrm{H}_{2}$ yield obtained $1.75 \mathrm{~mol} / \mathrm{mol}$ glucose [9].

However, to best of our knowledge, there was no study using RSM to optimize these three factors (starch, $\mathrm{Fe}^{2+}$ and L-cysteine) together. In this study, soluble starch, $\mathrm{Fe}^{2+}$ and L-cysteine played important roles for hydrogen production by anaerobic PL strain. In fact that starch was a substrate for bacteria growth. $\mathrm{Fe}^{2+}$ is an essential element to form key enzyme on hydrogen production, increasing of iron improve hydrogenase activity thus enhanced biohydrogen production [20]. $\mathrm{L}$-cysteine was reported to reduce OPR value of fermentation system. L-cysteine was also claimed to be a mediator between bacteria and substrate [17]. These reasons explained that three selected factors were necessary and all had significant affect to hydrogen production by anaerobic PL strain in our study.

The maximum $\mathrm{H}_{2}$ yield- $91.85 \mathrm{ml} / \mathrm{g}$ starch $\left(3.71 \mathrm{~mol} \mathrm{H}_{2} / \mathrm{g}\right.$ starch) obtained in the optimum condition higher than results in studies of Guo et al. $\left(2.20 \mathrm{~mol} \mathrm{H}_{2} / \mathrm{mol}\right.$ glucose $)$ and $\mathrm{Mu}$ et al. $\left(1.75 \mathrm{~mol} \mathrm{H}_{2} /\right.$ mol glucose) $[9,10]$. The reason was probably that adding amount of 


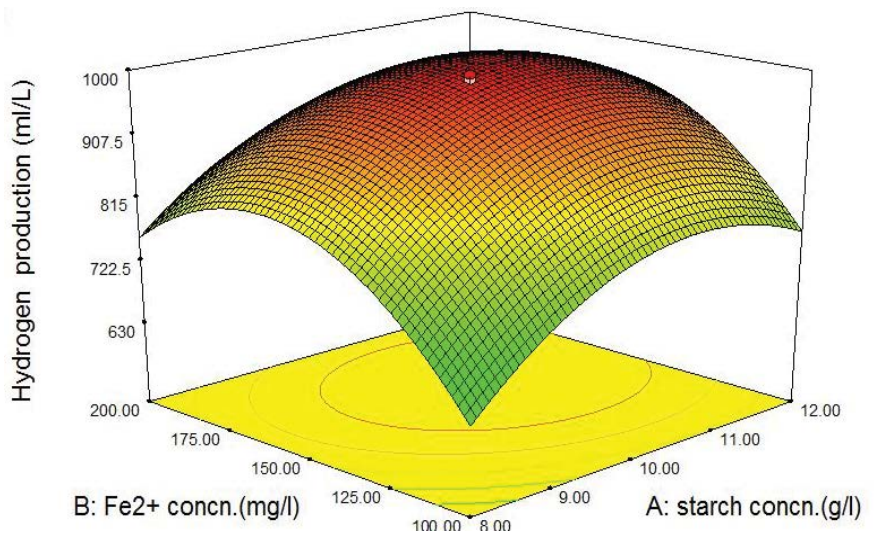

(a)

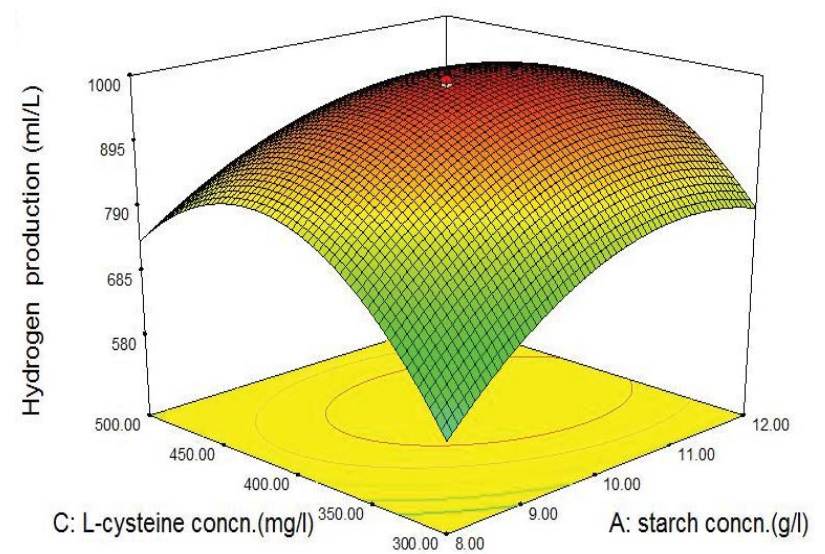

(b)

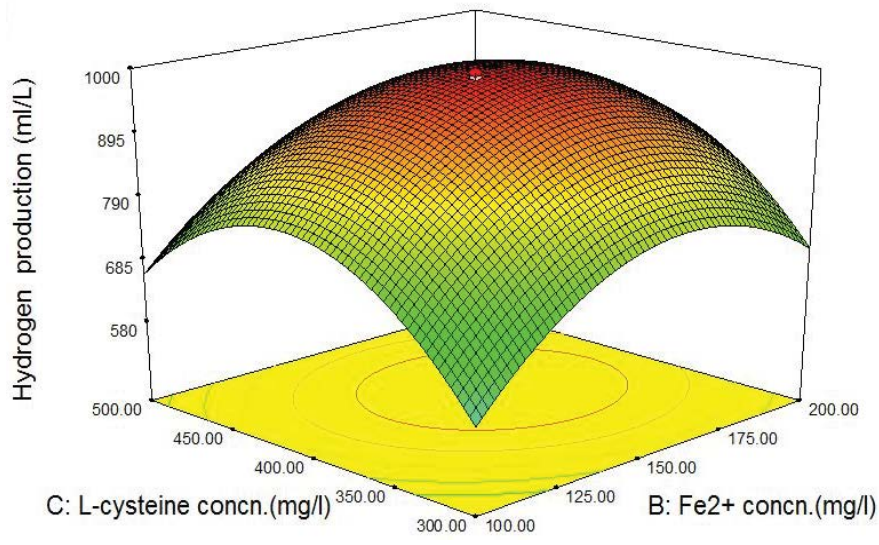

(c)

Figure 1: The response surface plot and the corresponding contour plot showing the effects of three factors on hydrogen production; (a) soluble starch and ferrous iron; (b) soluble starch and L-cysteine, (c) ferrous iron and L-cysteine.

L-cysteine increase the utility rate of the substrate resulting enhancing maximum hydrogen yield [21].

\section{Conclusion}

This study focused on the optimization of the key factors for enhancement the bio-hydrogen production using the statistical methodology. Experimental results showed that three independent variables (soluble starch, ferrous iron and L-cysteine) and interaction between them had significant influences on the hydrogen production potential. The optimum conditions for fermentation hydrogen were basal medium with $10 \mathrm{~g}$ soluble starch $\mathrm{L}^{-1}, 150 \mathrm{mg} \mathrm{Fe}^{2+} \mathrm{L}^{-1}, 400 \mathrm{mg}$ $\mathrm{L}$-cysteine $\mathrm{L}^{-1}$. In this optimum condition, maximum $\mathrm{H}_{2}$ gas obtained $91.85 \mathrm{ml} \mathrm{H}_{2} / \mathrm{g}$ starch (1030 $\mathrm{ml}$ total gas/L medium). The obtained results showed that the RSM was useful to optimize the hydrogen production process and to improve the hydrogen production potential by PL strain isolated in Vietnam.

\section{Acknowledgements}

The authors acknowledge financial supports from Department of Petroleum Microbiology, Institute of Biotechnology, Vietnam Academy of
Science and Technology. We would like to express our thanks for equipments supported by World University Service (WUS) within the scope of the APA support "Workplace Equipment Subsidies for Experts from Developing Countires) (APA2738).

\section{References}

1. Das D, Veziroglu TN (2008) Advances in biological hydrogen production processes. Int J Hydrogen Energy 33: 6046-6057.

2. Lee YJ, Miyahara T, Noike T (2001) Effect of iron concentration on hydrogen fermentation. Bioresour Technol 80: 227-231.

3. Yokoi H, Maki R, Hirose J, Hayashi S (2002) Microbial production of hydrogen from starch-manufacturing wastes. Biomass Bio-energy 22: 389-395.

4. Chen H, Xiaoxuan MA, Daidi F, Yane L, Peng G, et al. (2010) Influence of $\mathrm{L}-$ Cysteine Concentration on Oxidation-reduction Potential and Biohydrogen Production. Chinese J Chem Eng 18: 681-686.

5. Bao MD, Su HJ, Tan TW (2013) Dark fermentative bio-hydrogen production Effects of substrate pre-treatment and addition of metal ions or L-cysteine. Fue 112: 38-44.

6. Zhao X, Xing D, Liu B, Lu L, Zhao J, et al. (2012) The effects of meta ions and I-cysteine on hydA gene expression and hydrogen production by Clostridium beijerinckii RZF-1108. Int J Hydrogen Energy 37: 13711-13717. 
Citation: Kieu HTQ, Nguyen YT, Dang YT, Nguyen BT (2015) Optimization of Culture Conditions for Hydrogen Production by an Anaerobic Bacteria Strain on Soluble Starch Using Response Surface Methodology. J Bioprocess Biotech 5: 265 doi:10.4172/2155-9821.1000265

Page 6 of 6

7. Song $\mathrm{Y}$, Logan BE (2004) Effect of $\mathrm{O}_{2}$ exposure on perchlorate reduction by Dechlorosoma sp. KJ. Water Res 38: 1626-1632.

8. Taherdanak M, Zilouei H, Karimi K (2015) Investigating the effects of iron and nickel nanoparticles on dark hydrogen fermentation from starch using central composite design. Int J Hydrogen Energy 40: 12956-12963.

9. Mu Y, Zheng XJ, Yu HQ (2009) Determining optimum conditions for hydrogen production from glucose by an anaerobic culture using response surface methodology (RSM). Int J Hydrogen Energy 34: 7959-7963.

10. Liu G, Shen J (2004) Effects of culture and medium conditions on hydrogen production from starch using anaerobic bacteria. J Biosci Bioeng 98: 251-256.

11. Wang J, Wan W (2008) Effect of $\mathrm{Fe}^{2+}$ concentration on fermentative hydrogen production by mixed cultures. Int J Hydrogen Energy 33: 1215-1220.

12. Wang J, Wan W (2008) Experimental design methods for fermentative hydrogen production: A review. Int J Hydrogen Energy 34: 235-244.

13. Guo WQ, Ren NQ, Wang XJ, Xiang WS, Ding J, et al. (2009) Optimization of culture conditions for hydrogen production by Ethanoligenens harbinense B49 using response surface methodology. Bioresour Technol 100: 1192-1196.

14. (2007) Design-Expert ${ }^{\circledR} 7.1$ for windows-Software for Design of Experiments (DOE). Stat-Ease Inc., Minneapolis, USA.
15. Yoo YJ, Hong J, Hatch RT (1987) Comparison of alpha-amylase activities from different assay methods. Biotechnol Bioeng 30: 147-151.

16. Yang $\mathrm{H}$, Shen $\mathrm{J}$ (2006) Effect of ferrous iron concentration on anaerobic biohydrogen production from soluble starch. Int J Hydrogen Energy 3: 2137-2146.

17. Yuan Z, Yang H, Zhi X, Shen J (2008) Enhancement effect of I-cysteine on dark fermentative hydrogen production. Int J Hydrogen Energy 22: 6535-6540.

18. Zhang T, Liu H, Fang $\mathrm{HH}$ (2003) Biohydrogen production from starch in wastewater under thermophilic condition. J Environ Manage 69: 149-156.

19. Long C, Cui J, Liu Z, Liu Y, Long M, et al. (2010) Statistical optimization of fermentative hydrogen production from xylose by newly isolated Enterobacter sp. CN1. Int J Hydrogen Energy 35: 6657-6664.

20. Chen SD, Lee KS, Lo YC, Chen WM, Wu JF, et al. (2008) Batch and continuous biohydrogen production from starch hydrolysate by Clostridium species. Int $J$ Hydrogen Energy 33: 1803-1812.

21. Zhang Y, Liu G, Shen J (2005) Hydrogen production in batch culture of mixed bacteria with sucrose under different iron concentrations. Int $\mathrm{J}$ Hydrogen Energy 30: 855-860. 